\title{
PROFIL PROSES BERPIKIR MAHASISWA TIPE KEPRIBADIAN SENSING DALAM MEMECAHKAN MASALAH LOGIKA MATEMATIKA
}

\author{
M.J. Dewiyani $\mathbf{S}^{1}$, I Ketut Budayasa ${ }^{2}$, dan Dwi Juniati ${ }^{3}$ \\ 1. Institut Bisnis dan Informatika Stikom Surabaya, Indonesia, dewiyani@stikom.edu \\ 2 dan 3. Fakultas Matematika Unesa Surabaya, Indonesia
}

\begin{abstract}
Abstrak: Penelitian ini bertujuan untuk mengetahui profil proses berpikir mahasiswa dengan tipe kepribadian Sensing, yang terdiri atas Artisan dan Guardian, dalam menyelesaikan masalah matematika. Pengenalan terhadap profil berpikir mahasiswa penting diketahui oleh pengajar, karena melalui pengenalan tersebut, pengajar dapat mengembangkan model pembelajaran yang sesuai pada masing-masing tipe kepribadian sehingga proses pembelajaran dapat dicapai secara optimal. Mengenai tipe kepribadian, David Keirsey membagi menjadi tipe Sensing dan Intuisi. Pada penelitian ini, akan dibicarakan tipe Sensing, yang terbagi menjadi tipe Artisan dan Guardian. Subjek penelitian adalah mahasiswa jurusan Sistem Informasi sebuah perguruan tinggi di Surabaya. Metode yang digunakan adalah metode kualitatif eksploratif dimana subjek diminta untuk memecahkan masalah matematika menggunakan langkah heuristik dari Polya. Hasil penelitian menunjukkan bahwa profil proses berpikir mahasiswa dengan tipe Guardian lebih detail dan spesifik dalam memecahkan masalah matematika daripada tipe Artisan, yang lebih mengutamakan persoalan yang harus diselesaikan.
\end{abstract}

Kata Kunci: Pemecahan Masalah Matematika, Tipe Kepribadian, Sensing, Proses Berpikir.

\section{THINKING PROCESS PROFILE OF \\ SENSING STUDENTS' PERSONALITY TYPE IN SOLVING MATHEMATICAL PROBLEMS}

\begin{abstract}
The study was aimed to understand the thinking process profile of Artisan and Guardian students in solving mathematical problem. The importance of thinking process profile, an instructor can develop appropriate learning model for each personality type. So, the learning process can be optimized. The personality type is divided, by David Keirsey, into two types, Sensing and Intuition. In this research will be studied about Sensing type, which is divided into two, Artisan and Guardian. The subjects were students of Information Systems at a college in Surabaya. The used methods in this research is eksploratif qualitative method. This study is also using Polya for the step of mathematical problem solving, in order to get more knowledge about thinking process profile. The result shows that Guardian is more detail and more specific than Artisan, who is prioritize to finish the problem, in solve mathematical problems.
\end{abstract}

Key Words: Mathematic Problem Solving, Personality Type, Sensing, Thinking Process.

\section{PENDAHULUAN}

Pembelajaran matematika di sebuah perguruan tinggi khusus bidang teknologi informasi, terlebih di Jurusan Sistem Informasi bertujuan untuk melatih peserta didik agar dapat berpikir secara divergen dan runtun sebagai bagian untuk berpikir kritis sehingga dapat mengindentifikasi masalah serta memberikan solusi secara sistematis. Tujuan di atas dapat dicapai melalui beberapa mata kuliah berbasis matematika yang bertujuan untuk mengidentifikasi dan memecahkan masalah. Hal ini sesuai dengan pernyataan Sholiq (2004) yang menyatakan bahwa mata kuliah matematika di Jurusan Sistem Informasi bertujuan untuk mendasari kemampuan dalam pemrograman komputer berupa instruksi yang diberikan untuk memecahkan masalah.

Untuk mengembangkan program, terdapat tujuh langkah dasar yang harus dilakukan, yaitu mendefinisikan permasalahan, membuat outline solusi, mengembangkan outline ke dalam algoritma, menguji cobakan algoritma, menuliskan algoritma ke dalam kode bahasa pemrograman tertentu, menjalankan program, dan mendokumentasikan program. Pembelajaran matematika memberikan sumbangan pada langkah pendefini- 
sian permasalahan dan pembuatan outline solusi, yang merupakan langkah awal namun cukup penting bagi pengembangan program.

Dalam dunia pendidikan matematika, pemecahan masalah juga menjadi hal yang penting untuk ditanamkan pada diri peserta didik. Dengan pemecahan masalah matematika, membuat matematika tidak kehilangan maknanya, sebab suatu konsep atau prinsip akan bermakna kalau dapat diaplikasikan dalam pemecahan masalah. Selain itu, jika peserta didik sudah terbiasa untuk menyelesaikan masalah matematika, maka diharapkan pola pemecahan masalahnya akan digunakan untuk menyelesaikan masalah dalam kehidupan sehari-harinya.

Setelah disadari pentingnya pemecahan masalah matematika dalam dunia pendidikan matematika, sebagai pengajar tentu harus mengusahakan agar peserta didik mencapai hasil yang optimal dalam menguasai ketrampilan pemecahan masalah. Pendidik harus memikirkan cara menyajikan atau menyampaikan materi matematika dimana merupakan syarat mutlak yang harus dikuasai seorang guru matematika. Utami (2014) dan Fahyuddin (2015) menemukan dalam penelitiannya bahwa belajar secara individual lebih baik dibandingkandengan metode kolaboratif dalam mengembangkan kemampuan pemecahan masalah kimia secara matematis. Pada intinya, seorang pendidik harus terus mencari model pembelajaran yang paling tepat untuk mengajarkan topik pemecahan masalah.

Hudoyo (2003a) menyatakan bahwa untuk meningkatkan kemampuan peserta didik, salah satu cara adalah dengan memberikan metode mengajar yang tepat dan sesuai dengan peserta didik, agar mencapai hasil yang paling baik. Mengenai metode mengajar ini (Hudoyo, 2003b) melandasi dengan pernyataan, mengajar matematika merupakan suatu kegiatan pendidik agar peserta didiknya belajar menguasai matematika, yaitu kemampuan, ketrampilan dan sikap tentang matematika. Kemampuan, ketrampilan dan sikap yang dipilih pendidik itu harus relevan dengan tujuan belajar dan disesuaikan dengan struktur kognitif yang dimiliki peserta didik. Ini dimaksudkan agar terjadi interaksi antara pendidik dan peserta didik. Interaksi akan terjadi bila menggunakan cara yang cocok yang disebut metode mengajar matematika.

Metode mengajar matematika adalah suatu cara atau teknik mengajar matematika yang disusun secara sistematik dan logik ditinjau dari segi hakekat matematika dan segi psikologiknya (Stylianou, 2010). Metode mengajar ditinjau dari segi psikologik erat hubungannya dengan jawaban pertanyaan 'kepada siapa' matematika diajarkan. Metode yang tidak sesuai dengan peserta didik tidak akan dapat dicerna. Ini berarti, pendidik, harus menyadari pentingnya memahami perbedaan proses berpikir antar peserta didik maupun antara pendidik dan peserta didik.

Perbedaan proses berpikir dapat dipahamkan dengan pendekatan penggolongan kepribadian. Terdapat beberapa penelitian terdahulu yang telah mencoba untuk melihat kaitan antara perbedaan tingkah laku dan perbedaan proses berpikir peserta didik, diantaranya (Heerden, 2005), yang menggunakan pendekatan kuantitatif untuk melihat hubungan antara proses kognitif dengan salah satu penggolongan kepribadian, yaitu MBTI (Myers Briggs Type Indicator) dan (Zhang, 2002) yang melihat hubungan antara gaya berpikir dan penggolongan kepribadian Big Personality Traits.

Terdapat beberapa penggolongan kepribadian, salah satunya dilakukan oleh David Keirsey, seorang ahli psikologi dari California State University pada tahun 1984. Penggolongan tipe kepribadian oleh David Keirsey inilah yang akan digunakan pada penelitian ini, karena Keirsey menggolongkan tipe kepribadian bukan hanya berdasar pada pola tingkah laku yang nampak, namun lebih pada cara seseorang berpikir atau bersikap terhadap suatu masalah atau peristiwa.

Keirsey (1998)menggambarkan secara singkat penggolongan tipe kepribadian dimulai dari cara seseorang bersikap terhadap suatu peristiwa. Terdapat 2 cara yaitu bersifat observe dan introspective. Keirsey menggolongkan seorang yang bersifat observe sebagai tipe Sensing dan yang bersifat introspective sebagai tipe Intuitive. Seseorang yang termasuk dalam tipe Sensing, lebih membutuhkan informasi nyata, kenyataan yang real dan ingatan yang nyata unuk bersikap terhadap suatu peristiwa. Mereka sangat mementingkan pengalaman dan sejarah, ataupun hal-hal yang berdasar fakta yang telah pernah dijumpai. Sementara tipe Intuitive hanya memandang fakta sebagai sebuah data, untuk kemudian dikembangkan sendiri menjadi sebuah informasi. Tipe Intuitive lebih mementingkan untuk memikirkan apa yang terjadi di balik sebuah fakta, atau apa yang terjadi di kemudian hari, daripada hal yang terjadi di hari ini. 
Seseorang yang lebih bersifat observant, akan lebih 'membumi', dan lebih konkrit dalam memandang dunia, serta bertujuan untuk memperhatikan lebih pada kejadian-kejadian praktis, dan hubungan yang segera. Seorang observant, akan mengganggap segala yang dipentingkan lahir dari apa yang dialami, baik pengalaman itu kemudian dipastikan sebagai sesuatu yang benar (Judging), maupun pengalaman tersebut dibiarkan tetap terbuka seperti apa adanya (Perceiving). Keirsey menamakan orang yang bersifat Sensing dan Perceiving ini sebagai Artisan, dan orang yang bersifat Sensing dan Judging ini sebagai Guardian.

Seseorang yang lebih bersifat introspective, akan meletakkan rasio atau pemikiran di atas segalanya, dan lebih abstrak dalam memandang dunia, serta berfokus pada kejadian global. Bagi orang yang bersifat introspective, maka sangatlah penting baginya, untuk membentuk suatu konsep di dalam dirinya. Konsep yang dibentuknya, dapat berasal dari penalaran yang objektif dan tidak berdasar emosi (Thinking), atau konsep yang dibentuk berdasar perasaan atau emosinya (Feeling). Keirsey menamakan orang Introspective dan Thinking ini sebagai Rational, dan orang yang bersifat Introspective dan Feeling ini sebagai Idealist.

Secara singkat, bagan penggolongan tipe kepribadian menurut David Keirsey dalat dilihat pada Gambar 1.

Pada penelitian ini, eksplorasi proses berpikir akan difokuskan terlebih dahulu pada golongan Sensing, sementara pada golongan Intuitive akan dieksplorasi pada penelitian selanjutnya.
Secara umum, tipe kepribadian Guardian adalah tipe yang secara alamiah memiliki kecerdasan logistik (intelligence in logistic), yaitu kecerdasan untuk mengorganisasikan suatu masalah secara benar (Advisor, 2017). Bagi tipe Guardian, sebelum dimulainya suatu proses, maka segala hal harus dipastikan benar. Tipe Artisan memiliki kecerdasan alami dalam taktik (intelligence in tactics), yang berarti kemampuan untuk melihat situasi dengan cepat, mengevaluasi banyak pilihan, dan mengambil tindakan untuk mendapatkan hasil yang diinginkan (Advisor, 2017).

Keirsey (1998) menunjukkan perbedaan yang tampak dari tipe kepribadian Guardian dan Artisan seabgaimana ditunjukkan pada Tabel 1.

Proses berpikir yang hendak dilakukan adalah dalam pemecahan masalah karena pemecahan masalah menjadi sentral dalam pembelajaran matematika di tempat penelitian. Pada penelitian ini, masalah matematika diartikan secara khusus sebagai soal matematika yang berkaitan dengan soal jenis logika. Kekhususan ini diambil dengan menyelaraskan pada subjek penelitian kali ini, yaitu mahasiswa jurusan Sistem Informasi. Pada jurusan Sistem Informasi, soal-soal jenis logikadalam mata kuliah Logika, akan menjadi dasar pada beberapa mata kuliah pokok di jurusan Sistem Informasi, seperti Logika dan Algoritma, dan mata kuliah Pemrograman.

Langkah yang akan digunakan untuk memecahkan masalah dalam penelitian ini menggunakan langkah heuristik Polya (2014) yang terdiri atas memahami masalah, merencanakan penyelesaian masalah, menyelesaikan masalah, sampai pada melihat kembali penyelesaian masalah. Pemecahan masalah berdasar langkah Polya pen-

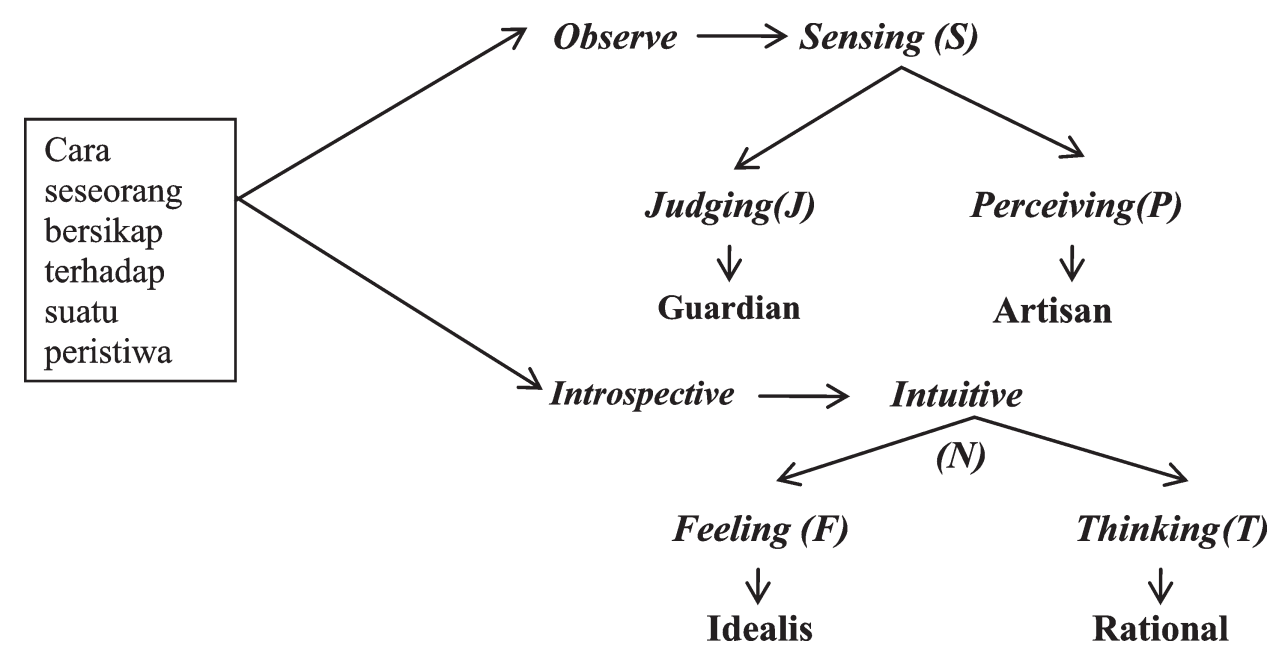

Gambar 1. Bagan Penggolongan Kepribadian menurut David Keirsey 
Tabel 1. Ciri Umum pada Setiap Tipe Kepribadian

\begin{tabular}{|c|c|}
\hline Guardian & Artisan \\
\hline $\begin{array}{l}\text { Sangat bertanggung jawab, pekerja keras, taat, } \\
\text { tepat jadwal, kaku, sulit berubah, } \\
\text { pengorganisasian kuat. }\end{array}$ & $\begin{array}{l}\text { Lebih mengutamakan hidup untuk hari ini, masa } \\
\text { lalu sudah tidak relevan lagi dan masa depan tidak } \\
\text { penting dan sangat cepat membuat keputusan tanpa } \\
\text { berpikir panjang, mampu melihat situasi dengan } \\
\text { cepat. }\end{array}$ \\
\hline $\begin{array}{l}\text { Sebagai peserta didik: } \\
\text { a. Menyukai kelas dengan pembelajaran yang } \\
\text { rutin berdasar prosedur yang ada, jadwal tidak } \\
\text { berubah-ubah. } \\
\text { b. Cocok dengan guru yang memberi penjelasan } \\
\text { secara gamblang, tepat dan konkret. } \\
\text { c. Materi harus disajikan berdasar kenyataan } \\
\text { yang terjadi pada masa lalu dan perkiraan } \\
\text { untuk masa depan. } \\
\text { d. Tidak menyukai gambar, tapi lebih suka pada } \\
\text { cerita. } \\
\text { e. Setiap tugas harus diketahui secara detail } \\
\text { terutama pada keuntungan yang didapat dari } \\
\text { tugas tersebut. }\end{array}$ & $\begin{array}{l}\text { Sebagai peserta didik: } \\
\text { a. Lebih menyukai ilmu terapan. } \\
\text { b. Selalu terlihat aktif di manapun. } \\
\text { c. Kegiatan yang disukai adalah demonstrasi, } \\
\text { presentasi, dan pengalaman belajar lain yang } \\
\text { melibatkan aksi. } \\
\text { d. Senang menceritakan hasil belajarnya kepada } \\
\text { teman lain. } \\
\text { e. Menyukai entertain. } \\
\text { f. Dalam mengerjakan tugas, harus diketahui } \\
\text { keuntungan yang didapatnya, dan relevansinya } \\
\text { terhadap materi yang ada pada saat itu. } \\
\text { g. Menyukai kompetisi, dan kesempatan untuk } \\
\text { bertanding. } \\
\text { h. Mampu mengubah keadaan sekitar. }\end{array}$ \\
\hline
\end{tabular}

ting dilakukan, agar dalam mengeksplorasi proses berpikir dapat dilakukan secara lebih mendalam dan terarah pada setiap langkah demi langkah. Pemecahan masalah diarahkan menggunakan langkah Polya karena menurut (Sukayasa, 2012) fase-fase pemecahan masalah menggunakan langkah Polya lebih populer digunakan dalam memecahkan masalah matematika dibandingkan yang lainnya. Mungkin hal ini disebabkan oleh beberapa hal antara lain: (1) fase-fase dalam proses pemecahan masalah yang dikemukan Polya cukup sederhana; (2) aktivitas-aktivitas pada setiap fase yang dikemukakan Polya cukup jelas dan; (3) fase-fase pemecahan masalah menurut Polya telah lazim digunakan dalam memecahkan masalah matematika

Pada jurusan Sistem Informasi ini pula, telah dilakukan penggolongan tipe kepribadian berdasar David Keirsey, yang menghasilkan terdapatnya anggota dari masing-masing tipe kepribadian, sehingga dimungkinkan untuk dieksplorasi proses berpikir pada mahasiswa berbasis perbedaan tipe kepribadian, sehingga diharapkan dapat dikembangkan pembelajaran matematika yang lebih menghargai setiap individu, dan bukan secara klasikal saja.

Berdasar latar belakang yang ada, dan kajian teori terkait, maka masalah yang mun- cul pada penelitian ini adalah bagaimana hasil eksplorasi proses berpikir mahasiswa jurusan Sistem Informasi tipe kepribadian Guardian dan tipe kepribadian Artisan, hingga didapat profil proses berpikirnya dalam memecahkan masalah matematika.

Menyesuaikan dengan permasalahan yang ada, maka tujuan penelitian ini adalah mengeksplorasi proses berpikir mahasiswa jurusan Sistem Informasi tipe Guardian dan Artisan dalam memecahkan masalah matematika.

Manfaat yang didapatkan dari hasil eksplorasi proses berpikir tipe Sensing adalah untuk pengembangan model pembelajaran matematika berbasis perbedaan proses berpikir berdasar tipe kepribadian, sehingga diharapkan model pembelajaran yang terjadi dapat lebih menghargai setiap peserta didik secara lebih pribadi, dan akan membawa peserta didik pada suatu proses belajar yang lebih nyaman dan efektif, karena sesuai dengan proses berpikir peserta didik tersebut.

\section{METODE}

Penelitian ini bertujuan untuk mengeksplorasi proses berpikir mahasiswa golongan Sensing dalam memecahkan masalah matematika sehingga diambil metode penelitian eksploratif melalui pendekatan kualitatif (Huberman, 2009). 
Penelitian eksploratif karena mengeksplorasi proses berpikir, dengan data utamanya berupa kata-kata yang dirangkaikan menjadi kalimat. Pendekatan kualitatif dipilih karena penentuan profil berpikir mahasiswa dalam menyelesaikan masalah matematika berlatar alamiah dan instrumen utama penelitian ialah peneliti sendiri (Suriansyah, 2015). Analisis dilakukan secara mendalam pada mahasiswa tentang pemecahan masalah matematika, setelah mahasiswa dibagi berdasar tipe kepribadiannya.

Subjek diambil dari mahasiswa program studi S1 Sistem Informasi sebuah perguruan tinggi di Surabaya. Pemilihan subjek dimulai dengan cara memberikan tes penggolongan tipe kepribadian menggunakan perangkat tes dari David Keirsey (Keirsey, 1998). Setelah semua tipe terisi, dipilih mahasiswa dengan indikasi terkuat sebagai subjek dari golongan Guardian dan Artisan. Terhadap mahasiswa yang terpilih sebagai calon subjek penelitian, dilakukan tes kepribadian ulang, guna lebih memastikan apakah subjek yang dimaksud sudah dipastikan termasuk dalam tipe Guardian dan Artisan sebab tes yang pertama dilakukan secara klasikal sehingga dapat dipastikan apakah subjek menjawab dengan bersungguh-sungguh serta tidak terjadi kekeliruan terhadap pemahaman suatu pertanyaan (Suriansyah, 2015).

Masrukan(2015) dan Denzin (2011) mengemukakan pertanyaan dalam wawancara dapat berupa pertanyaan pengetahuan dan pertanyaan tingkah laku, sehinggasetelah penggolongan tipe kepribadian dilakukan.Data yang dibutuhkan dalam penelitian ini adalah (i) transkrip wawancara subjek golongan Guardian dan Artisan dalam memecahkan masalah matematika beserta tulisan yang dibuat pada waktu menyelesaikan masalah; (ii) pengamatan terhadap tingkah laku subjek penelitian pada saat menyelesaikan masalah. Semua data didapatkan melalui wawancara klinis dan direkam melalui audio visual agar dapat diputar ulang untuk diamati secara lebih teliti. Pertanyaan pengetahuan adalah pertanyaan yang dimaksudkan untuk mengungkap proses berpikir subjek tentang apa yang menurutnya sebagai informasi faktual yang sedang diteliti. Pengamatan tingkah laku adalah pengamatan yang dimaksudkan untuk mengungkap deskripsi pengalaman, tingkah laku, tindakan dan kegiatan yang telah teramati oleh peneliti, dengan harapan dapat mengakses persepsi subjek. Pengamatan ini dilakukan kare- na penggolongan yang dilakukan berdasar pada tipe kepribadian, di mana perbedaan tingkah laku menjadi pembeda antar tipe.

Pengambilan data dilakukan tidak hanya satu kali pada setiap subjek, namun dimungkinkan beberapa kali sesuai dengan kebutuhan peneliti akan tersedianya data seperti yang diinginkan (Suriansyah, 2015). Pemecahan masalah matematika oleh subjek penelitian digali berdasar langkah Polya.

Masalah yang diberikan adalah masalah logika, agar sesuai dengan materi Logika yang dibutuhkan oleh subjek penelitian pada perkuliahan di jurusan Sistem Informasi. Dalam penelitian ini, untuk menjamin validitas, diadakan wawancara sebanyak dua kali.

Proses analisis data dilakukan dengan penelaahan dan pengelompokkan data. Pengelompokkan data dilakukan setelah pengambilan data selesai dilakukan, dengan terlebih dahulu melakukan transkrip wawancara, sesuai dengan poin-poin proses berpikir subjek yang ingin diketahui oleh peneliti. Pada waktu pengelompokan data, akan terdapat tiga hal yang disoroti oleh peneliti pada setiap poin, yaitu dari hasil pekerjaan, pengamatan terhadap tampak luar (secara fisik, kasat mata), dan proses berpikir yang didapat dari hasil wawancara, kemudian dilakukan pemeriksaan keabsahan data atau validasi data, dengan melakukan pengecekan berulang dengan waktu dan alat yang berbeda. Oleh Moleong (2013), hal ini digolongkan ke dalam triangulasi waktu, yaitu membandingkan dan mengecek balik derajat kepercayaan suatu informasi yang diperoleh melalui waktu dan alat yang berbeda.

Data atau informasi dikatakan valid jika ada konsistensi, kesamaan pandangan, pendapat atau pemikiran pada pengecekan pertama dan pengecekan kedua, setelahnya dilakukan pemaparan data, meliputi klasifikasi dan identifikasi. Hal ini dimaksudkan untuk mempermudah menarik kesimpulan dari data tersebut, dan yang terakhir penafsiran data dan penarikan kesimpulan. Penarikan kesimpulan didasarkan pada hasil analisis terhadap data yang telah terkumpul, baik yang diperoleh dengan menggunakan tes maupun yang diperoleh dari hasil wawancara (Merriam, 2015). Selanjutnya penarikan kesimpulan pada penelitian ditujukan untuk merumuskan profil proses berpikir mahasiswa dalam memecahkan masalah logika matemaika. 


\section{HASIL DANPEMBAHASAN Hasil}

Pada bagian inidipaparkan hasil analisis untuk menjawab pertanyaan penelitian berupa profil proses berpikir terhadap golongan Sensing. Keirsey (Keirsey, 1998) menggolongkan Sensing ke dalam dua tipe kepribadian, yaitu Guardian dan Artisan sehingga pada masing-masing paparan akan ditampilkan hasil eksplorasi proses berpikir tipe Guardian dan tipe Artisan.Jenis soal logika yang biasanya digunakan pada mata kuliah Logika sehingga subjek telah mendapatkan pengetahuan tentang pengambilan simpulan dalam ilmu Logika.

Salah satu soal logika yang diberikan adalah: Ibu Tina, seorang ibu rumah tangga, suatu pagi bangun dan merasakan sakit kepala. Bergegaslah Ibu Tina ke dokter Budi, seorang dokter yang tinggal di dekat Ibu Tina. Dia segera mengeluhkan sakit kepala yang dideritanya, dan Ibu Tina juga menceritakan riwayat obat-obat yang pernah diminumnya beserta efek sampingannya.

Berikut riwayat obat yang pernah diminum oleh Ibu Tina: (a) Jika ibu Tina minum Aspirin, sakit kepala sembuh dan dapat menolong penyakit rematik pada lututnya, tetapi membuat mual dan mengganggu perut. (b) Jika ibu Tina minum Obat-obatan herbal (obat yang terbuat dari tumbuh-tumbuhan), rasa mual dan gangguan perutnya sembuh, tetapi menyebabkan sakit pada persendian kaki. (c) Jika ibu Tina minum Antibiotik, sakit kepala dan mualnya sembuh, tetapi membuat gangguan pada perut, rematik pada lutut, dan leher kaku. (d) Jika ibu Tina minum Cortisone, kaku pada leher dan rematik pada lututnya akan sembuh, tetapi menyebabkan sakit pada persendian kaki. (e) Jika ibu Tina melakukan kompres dengan lap hangat, dapat meringankan gangguan perut dan kekakuan pada leher. Menurut Anda, obat apa yang harus diberikan oleh dokter Budi, agar Ibu Tina sembuh dari sakit kepala, namun tidak menimbulkan efek samping?

\section{Profil proses berpikir tipe kepribadian Guar- dian dalam memecahkan masalah logika matematika yang digunakan dalam perkulia- han Logika}

Hasil eksplorasi terhadap dua mahasiswa dengan tipe Guardian, yang diberi inisial GS pada saat diberi masalah logika dengan berdasar pada tahap pemecahan masalah dari Polya, dan dengan berdasar indikator pengamatan yang telah dibuat sebelumnya adalah sebagai berikut.

\section{Tahap Pemahaman Masalah}

Ketika diberi soal logika, dengan terlebih dahulu mengutamakan subjek sedang dalam kondisi prima dan tanpa tekanan serta diusahakan wawancara dilakukan sesantai mungkin, hasil pengamatan tampak bahwa subjek membaca soal dengan diam, tanpa kata-kata, menunjuk dengan bolpoin, sering menopang tangan di dagu, dan kelihatan tenang.

Dalam usaha untuk memahami masalah, subjek mencoba untuk menangkap situasi pada soal yang dilakukan dengan membaca secara urut dan utuh. Subjek membaca dua kali pada bagian yang dianggap penting oleh subjek serta merupakan titik tolak bagi subjek untuk menangkap situasi pada soal. Ini berarti kerangka permasalahan sudah dikuasai dengan baik oleh subjek.

Setelah kerangka permasalahan telah didapatkan, hasil wawancara mengungkap cara GS menemukan hal yang diketahui dan ditanyakan. Subjek GS dapat menentukan hal yang diketahui dan ditanyakan dengan baik. Hal yang diketahui ditentukan berdasar fungsi kalimatnya, sedang hal yang ditanyakan berdasar jenis kalimatnya. Antara hal yang diketahui dan ditanyakan, diyakini oleh subjek GS saling terkait, berdasarkan kesamaan. Seluruh pemahaman masalah kemudian disimpan dalam pemikiran subjek GS, dengan mengingat poin masalah (obat apa yang digunakan), kemudian melakukan analisis dan menyimpan poin serta analisis untuk kemudian digunakan pada tahap selanjutnya.

\section{Tahap Perencanaan Penyelesaian Masalah}

Pada saat merencanakan penyelesaian masalah, subjek GS mengerjakansambil menunjuk dengan bolpoin pada kalimat yang dituju, dan dilakukan secara yakin serta tenang. Subjek merencanakan pemecahan masalah berdasar inti kalimat(seperti terungkap pada petikan transkrip kalimat dari subjek GS : "Jadi rencana saya yang pertama yang ditanyakan kan sakit kepala. Dicari obat pertama kali yang dapat menyembuhkan sakit kepala. Yang dapat menyembuhkan sakit kepala aspirin dan antibiotik. Yang ditanyakan tidak boleh menimbulkan efek samping. Berarti meskipun ada efek sampingnya nggak papa tetapi kita harus mencari obat lain untuk menyembuhkan efek samping itu. Kemudian kita mencari obat 
sampai anu.... em maksudnya efek samping ini bisa disembuhkan obat-obat lainnya"). Pada saat merencanakan pemecahan masalah, subjek telah menyimpulkan bahwa informasi yang ada, tidak cukup untuk menyelesaikan masalah. Kesimpulan ini sebenarnya diambil dengan agak tergesa, sesuai dengan sifat Judging, yaitu cepat mengambil keputusan.

\section{Tahap Penyelesaian Masalah}

Ketika sampai pada tahap penyelesaian masalah, subjek menuliskan secara urut penyelesaian masalah. Subjek mengerjakan penyelesaian masalah secara urut, sesuai dengan urutan penyebutan pada soal, kemudian setelah ditemui kegagalan, maka subjek mengubah urutan pengerjaan, hingga didapatkan penyelesaiannya. Dari hasil penyelesaian masalah, subjek menyadari bahwa data yang dianggap kurang pada saat tahap perencanaan masalah, ternyata tidak terbukti.

\section{Tahap Pemeriksaan Kembali Penyelesaian Masalah}

ada saat diberi kesempatan untuk memeriksa kembali jawaban, subjek tidak menuliskan apapun dalam lembar jawab. Subjek menggunakan cara yang digunakan pada waktu menyelesaikan masalah, namun dengan memusatkan pada ketiga obat yang telah diketemukan dalam langkah sebelumnya, untuk memeriksa setiap langkah penyelesaian. Ini berarti subjek menggunakan hasil yang telah didapat, kemudian mendaftar khasiat dan efek samping dari obat tersebut.

Dari hasil ekplorasi terhadap tipe Guardian didapatkan dalam memahami masalah, tipe ini membaca soal sebanyak dua kali yang menunjukkan sifat teliti dan tekun, dan hendak membuat segala sesuatunya pasti sebelum mengerjakan sesuatu, selain itu, tipe Guardian dapat menemukan inti kalimat, untuk dijadikan titik tolak penyelesaian. Fokus, dan selalu memastikan segalanya berjalan dengan baik, memang merupakan salah satu ciri dari tipe ini (Masrukan, 2015)(Zarafshani, 2011). Dalam merencanakan penyelesaian masalah, tipe ini memunyai rencana yang terstruktur dengan berdasar fakta yang terdapat pada masalah dan diterapkan secara teliti dalam penyelesaian karena tipe ini termasuk tipe yang melakukan segalanya penuh dengan rencana yang matang (Doe, 2010). Selain itu, tampak bahwa tipe ini punya keyakinan diri yang matang yang ditunjukkan dengan ketika memeriksa kembali jawaban tidak menuliskan sesuatu dan tetap menggunakan cara yang sama. Hal ini juga ditemukan oleh Gungor (2014) yang menyatakan bahwa tipe Guardian memiliki keyakinan diri yang paling tinggi dibanding tipe yang lain

Pemanfaatan seluruh data berdasar fakta yang nampak, memang menjadi ciri dari tipe ini, karena tipe ini termasuk dalam tipe Sensing yang selalu melihat fakta sebagai acuan dalam melaksanakan penyelesaian (Keirsey, 1998). Setelah menyelesaikan masalah, tipe ini tidak memerlukan cara lain untuk meyakinkan kebenaran hasil, cukup dengan mengulang kembali semua pekerjaan yang telah dibuatnya, sesuai dengan sifat dari tipe Sensing, yaitu segera memutuskan masalah, dan tidak menundanya.

Profil Proses Berpikir Tipe Kepribadian Artisan Masalah Logika Matematika yang Digunakan dalam Perkuliahan Logika

Agar lebih mendapatkan hasil eksplorasi yang mendalam, maka profil proses berpikir dirinci berdasar langkah Polya, yaitu dibagi menjadi empat tahap.

\section{Tahap Pemahaman Masalah}

Ketika diberi soal logika, dengan terlebih dahulu mengutamakan subjek sedang dalam kondisi prima dan tanpa tekanan serta diusahakan wawancara dilakukan sesantai mungkin, dari hasil pengamatan tampak hasil eksplorasi terhadap 2 mahasiswa dengan tipe Artisan, yang diberi inisial AS, membaca soal tanpa pengucapan sambil badan terlihat banyak bergerak-gerak, ekspresi wajah sering berubah, sering menggaruk leher bagian belakang, dan tidak menulis.

Dalam usaha untuk memahami masalah, tanpa membaca kalimat yang lain, subjek langsung mencari pertanyaan denganagak tergesa. Setelah membaca satu kali, subjek membaca lagi sebanyak 2 kali, hal ini dikarenakan ada hal yang terlupa.Dalam menangkap situasi pada soal, subjek lebih mementingkan pertanyaan, baru kemudian hal yang lain. dan subjek menangkap situasi pada soal dengan memaknai pertanyaan tersebut. Kerangka permasalahan juga sudah dapat dikuasai dengan baik(seperti terungkap pada petikan transkrip kalimat dari subjek AS: "oh.. saya mikir obatnya, karena setiap obat dapat membuat sembuh..tapi selalu ada efek sampingnya (sambil tersenyum)..terus gimana supaya aku bisa menghilangkan sakitnya itu...kemudian dilakukan 
penggabungan, karena kalau dilakukan penggabungan, efek sampingnya kan jadi hilang.... (senyum sambil menggaruk telinga)").

Setelah kerangka permasalahan didapatkan, dari hasil wawancara terungkap cara subjek AS menemukan hal yang diketahui dan ditanyakan. Hal yang diketahui didapat berdasar kegunaan informasi itu untuk menjawab pertanyaan, sedang hal yang ditanyakan berdasar jenis kalimatnya. Antara hal yang diketahui dan ditanyakan, diyakini oleh subjek saling terkait, berdasar pemaknaan kata. Seluruh pemahaman masalah kemudian disimpan oleh subjek AS, dalam bentuk tulisan, dengan membuat rangkuman.

\section{Tahap Perencanaan Penyelesaian Masalah}

Pada saat merencanakan penyelesaian masalah, dari pengamatan terhadap gerakan tubuh, subjek banyak membuat gerakan tubuh, menggeleng-geleng, garuk-garuk kepala, garukgaruk hidung, serta sambil memperagakan hal yang dikatakannya, dan menggunakan kalimat pendek. Subjek merencanakan pemecahan masalah, tidak berdasar pada pengalaman memecahkan masalah yang mirip, namun karena penguasaan terhadap masalah itu sendiri. Rencana dibuat dengan terlebih dahulu menuliskan ulang informasi yang ada. Pada saat merencanakan penyelesaian masalah, subjek menyimpulkan bahwa informasi yang diberikan cukup untuk menyelesaikan masalah, bahkan mungkin berlebih. Analisis ini didasarkan pada adanya kaitan antara informasi yang satu dan yang lain.

\section{Tahap Penyelesaian Masalah}

Ketika menyelesaikan masalah, urutan yang dikerjakan oleh subjek adalah menuliskan kembali informasi yang ada, mencari kaitan antara informasi yang satu dengan yang lain, dan membuat analisis. Ketika terjadi kegagalan, subjek mengulang kembali cara penyelesaian masalah dengan berfokus pada pertanyaan.

\section{Tahap Pemeriksaan Kembali Penyelesaian Masalah}

Dalam memeriksa seluruh langkah penyelesaian, subjek tampak kurang yakin, dan merasa tidak mengetahui cara memeriksa jawabannya, hanya setelah beberapa saat, subjek menemukannya. Subjek menjawab dengan kalimat pendekpendek dan sering memperlihatkan wajah yang ekspresif.
Subjek memeriksa kembali jawaban dengan cara membaca kembali pertanyaan yang ada, kemudian baru memeriksa kembali seluruh langkah penyelesaian yang telah dilakukan.Dari hasil eksplorasi didapatkan, pada tipe Artisan dalam keseluruhan kegiatan eksplorasi, tipe ini menunjukkan banyak membuat gerakan tubuh, yang disebabkan karena tipe ini memang tidak menyukai sesuatu yang statis, dan ingin selalu berubah (Brandon, 2010).

Tipe ini lebih mementingkan bagian pertanyaan, karena tipe ini selalu fokus pada apa yang akan terjadi dan bukan apa yang telah terjadi, sehingga ketika memahami masalah, tipe ini merasa akan dapat memahami masalah dengan baik setelah mengetahui apa yang harus diselesaikannya (Masrukan, 2015).

Dalam merencanakan penyelesaian masalah, tipe ini selalu menggunakan cara praktis dan sesuai dengan fakta yang ada, karena memang tipe ini termasuk ke dalam tipe Sensing, yang selalu melihat fakta sebagai acuan dalam melaksanakan penyelesaian. Karena sifat yang selalu ingin berubah (Brandon, 2010)menyebabkan tipe ini sering tidak menggunakan hal yang telah direncanakan untuk menyelesaikan masalah. Cara yang digunakan saat merencanakan penyelesaian masalah, bahkan digunakan saat memeriksa kembali penyelesaian.

Setelah profil proses berpikir pada tipe Guardian dan Artisan diketahui, maka pengajar dapat merencanakan proses pembelajaran dengan menyesuaikan pada profil yang didapat, yaitu dengan membuat rencana pembelajaran maupun lembar kerja serta perangkat lain, yang sesuai dengan profil proses berpikir tipe Guardian dan Artisan.

Penelitian selanjutnya akan dibuat pada tipe Intuisi yaitu Rational dan Idealis. Setelah profil proses berpikir pada tipe Rational dan Idealis didapatkan, maka perangkat pembelajaran juga dapat dibuat.

Dengan demikian, setiap pribadi akan belajar sesuai dengan tipe kepribadiannya. Hal ini berarti, sebagai pengajar telah memperlakukan setiap peserta didik secara pribadi, dan bukan klasikal, meskipun proses belajar dilaksanakan bersama-sama dalam satu kelas.

\section{SIMPULAN}

Profil proses berpikir mahasiswa golongan Sensing yang dibagi menjadi tipe Guardian dan 
Artisan, dalam memecahkan masalah logika adalah sebagai berikut.

\section{Tipe Guardian}

Dalam memahami masalah, tipe guardian selalu membaca soal sebanyak 2 kali secara urut dan utuh, lebih berfokus pada mengambil inti kalimat, untuk menentukan titik tolak penyelesaian, hingga dapat digunakan untuk mendapatkan gambaran penyelesaian masalah.Tidak membuat tulisan pada waktu menyimpan informasi, dan bersikap tenang dalam memahami masalah.

Dalam merencakan penyelesaian masalah, tipe guardian telah mempunyai rencana terstruktur yang menggambarkan penyelesaian masalah, didasarkan pada fakta, dan tidak menuangkan dalam bentuk tulisan. Saat menyelesaikan masalah, tipe ini menggunakan prosedur sesuai dengan rencana terstuktur yang telah direncanakan pada tahap sebelumnya, tanpa mengalami perubahan. Pada waktu memeriksa kembali penyelesaian masalah, hanya memeriksa beberapa langkah penyelesaian yang digunakan dan tidak berusaha untuk menyelesaikan dengan menggunakan cara baru.

Secara umum tipe Guardian adalah tipe yang serius dan fokus, namun selalu ingin segera menyelesaikan masalah dan tidak suka pada masalah yang terlalu panjang. Dalam hal ini, pendidik dapat merencanakan pembelajaran yang langsung pada inti masalah, maupun soal yang tidak menggunakan kata-kata yang panjang, agar tipe ini dapat tetap berfokus pada masalah yang harus diselesaikan.

\section{Tipe Artisan}

Dalam memahami masalah, soal dibaca sebanyak tiga kali, dengan memberikan penekanan terutama pada pertanyaan. Tipe ini memberikan coretan dan catatan sebagai penanda untuk membantu memahami masalah. Fokus utama dari tipe ini adalah pada pertanyaan yang harus dijawab. Setelah pertanyaan dipahami, baru diulang kembali untuk membaca masalahnya. Pada saat memahami masalah, segala sesuatunya lebih ditekankan pada manfaat dari setiap kalimat. Jika pada kalimat tersebut memunyai manfaat akan diberi tanda.

Dalam merencanakan penyelesaian masalah, tipe ini banyak membuat penulisan, dan mencoba menggunakan pengetahuan terdahulu yang telah diterima, dengan mengingatnya kembali. Saat menyelesaikan masalah, tipe ini mengguna- kan rencana yang telah dibuat, dengan tetap fokus pada pertanyaan. Pada saat diminta memeriksa kembali penyelesaian masalah, pada awalnya tipe ini tidak tau apa yang harus dikerjakan, namun pada akhirnya, justru menggunakan cara yang berbeda dari yang telah dikerjakan. Hal ini menunjukkan bahwa tipe ini mempunyai keragaman cara dalam menyelesaikan masalah.

Secara umum, tipe Artisan adalah tipe yang selalu ingin mengetahui apa yang akan dipelajari atau apa yang harus diselesaikan. Dalam hal pembelajaran, pendidik misalnya dapat merencanakan pembelajaran dengan menyebutkan terlebih dahulu tujuan pembelajaran, ataupun menyebutkan masalahnya terlebih dahulu pada soal yang harus diselesaikan oleh tipe ini.

\section{UCAPAN TERIMAKASIH}

Penelitian ini dilaksanakan di Institut Bisnis dan Informatika Stikom Surabaya dengan bantuan pembimbing dari Universitas Negeri Surabaya, oleh karenanya penulis mengucapkan terimakasih kepada Institut Bisnis dan Informatika Stikom Surabaya dan Universitas Negeri Surabaya, serta Direktorat Pendidikan dan Kebudayaan Indonesia, melalui penelitian Hibah Bersaing, sehingga penelitian ini dapat diselesaikan. Ucapan terima kasih juga penulis haturkan kepada tim Editor dari Jurnal Cakrawala Pendidikan Universitas Negeri Yogyakarta dan kepada reviewer yang telah memberikan kesempatan, hingga artikel ini dapat dipublikasikan.

\section{DAFTAR PUSTAKA}

Advisor, K. C. 2017. Keirsey.com. Retrieved Mei 31, 2017, from http://www.keirsey.com/ personalityzone/cz34.asp

Brandon, A. M. 2010. "Use Of Mbti Personality Typing As An Aid To Communication When Dealing With Spiritual Injury/ Distress In Specialist Palliative Care". Scottish Journal of Healthcare Chaplaincy , 19-24.

Denzin, N. 2011. Handbook of Qualitative Research. Yogyakarta: Pustaka Pelajar.

Doe, J. 2010. The Kerisey Temperament Sorter II, Learning Styles Temperament Report. Keirsey.com. 
Fahyuddin. 2015. "Perbandingan Metode Kolaborasi dengan Contoh Tugas dan Belajar Individual dalam Pengembangan Kemampuan Pemecahan Masalah Kimia”. Cakrawala Pendidikan, 34 - 46.

Gungor, F. 2014. The Relationship Between Personality Types and Self efficacy perceptions of student teachers. 5th World Conference on Educational Sciences - WCES 2013 (pp. 786-790). Elsevier.

Heerden, G. V. 2005. The relationship Between the Cognitive Process Profile and The Myers Briggs Type Indicator. University of South Africa.

Huberman, M. 2009. Analisis Data Kualitatif, Buku Sumber tentang Metode Metode Baru. Jakarta: Penerbit Universitas Indonesia.

Hudoyo, H. 2003a. Pengembangan Kurikulum dan Pembelajaran Matematika. Malang: Universitas Negeri Malang.

Hudoyo, H. 2003b. Mengajar Belajar Matematika. Jakarta: Departemen Pendidikan dan Kebudayaan.

Keirsey, D. 1998. Please Understand Me II. Canada: Prometheus Nemesis Book Company.

Masrukan. 2015. “Analysis of Mathematical Communication Ability Through 4K Model Based on 7th Grades Personality Types". International Journal of Educational and Research, 343-352.

Merriam, S. B. 2015. Qualitative Research, a Guide to Design and Implementation, Fourth Edition. United States of America: Jossey Bass.
Moleong, L. 2013. Metodologi Penelitian Kualitatif edisi Revisi. Bandung: PT Remaja Rosda Karya.

Polya. 2014. How to Solve It: A New Aspect of Mathematical Method. USA: Princeton Science Library.

Sholiq. 2004. Buku Materi Kuliah Stikom: Logika dan Algoritma. Surabaya: Stikom Surabaya.

Stylianou. 2010. "Teachers' Conception of Representation in Middle School Mathematics". Journal of Mathematics Teacher Education, 325-343.

Sukayasa. 2012. Pengembangan Model Pembelajaran Berbasis Fase-Fase Polya untuk Meningkatkan Kompetensi Penalaran Siswa SMP dalam Memecahkan Masalah. Aksioma, 48-57.

Suriansyah, A. 2015. "Strategi Kepempinan Kepala Sekolah, Guru, Orang Tua dan Masyarakat dalam Membentuk Karakter Siswa". Cakrawala Pendidikan, 234-247.

Utami, M. 2014. "Implementasi Pengembangan Perangkat Pembelajaran Matematika Realistik di Sekolah Menengah Pertama”. Cakrawala Pendidikan, 463-473.

Zarafshani, K. 2011. "Using the MBTI in Teaching of Entrepreneurial Skills". International Journal of Science and Technology Education, 67-74.

Zhang, L. F. 2002. Thinking Styles and the Big Five Personality Traits. Educational Psychology. 